\title{
Penerapan Diversi Undang-Undang No 11 Tahun 2012 Tentang Sistem Peradilan Pidana Anak (Studi Kasus Polres Sorong Kota)
}

\author{
Wahab Aznul Hidaya ${ }^{1,}$ Muharuddin Muharuddin ${ }^{2,}$ Wilgos Gabreilla Manuputty ${ }^{3}$ \\ Ilmu Hukum, Universitas Muhammadiyah Sorong \\ Email : wahabaznulhidaya@gmail.com ${ }^{1}$, amuharuddin@gmail.com ${ }^{2}$, \\ wilgosgabreillam1@gmail.com ${ }^{3}$
}

\begin{abstract}
Increased criminal behavior by children should not have to occur so prevention efforts must be done. One of the efforts to prevent and tackle child delinquency (child crime politics) currently through the administration of the juvenile justice system. The purpose of the implementation of the juvenile justice system is not merely aimed at imposing criminal sanctions on children who have committed a crime, rationale. The method used in this study is empirical juridical namely a study conducted on real conditions for the community around the environment with the intent and purpose of finding facts and then leading to problem solving. Diversion must be pursued at the level of investigation, the level of prosecution and examination of cases of children in court. Word "Must be tried" implies that child law enforcement from educators, public prosecutors as well as judges are required to make efforts so that the diversion process can be carried out, Public prosecutors and judges are also required to make efforts so that the diversion process can be carried out.
\end{abstract}

Keywords : Juvenile Justice System, Diversion, Restorative Justice.

\begin{abstract}
Abstrak
Meningkatnya perilaku tindak pidana yang dilakukan oleh anak semestinya tidak harus terjadi sehingga upaya pencegahan haruslah dilakukan. Salah satu upaya pencegahan dan penanggulangan kenakalan anak (politik kriminal anak) saat ini melalui penyelenggaraan sistem peradilan anak (juvenile justice). Tujuan penyelenggaraan sistem peradilan anak tidak semata-mata bertujuan untuk menjatuhkan sanksi pidana bagi anak yang telah melakukan tindak pidana, akan tetapi lebih difokuskan pada dasar pemikiran bahwa penjatuhan sanksi tersebut sebagai sarana mendukung mewujudkan kesejahteraan anak pelaku tindak pidana. Adapun Metode yang digunakan dalam penelitian ini yakni yuridis empiris yaitu suatu penelitian yang dilakukan terhadap keadaan yang nyata bagi masyarakat dilingkungan sekitar dengan maksud dan tujuan untuk menemukan fakta kemudian menuju kepada penyelesaian masalah. Diversi wajib diupayakan pada tingkat penyidikan, tingkat penuntutan maupun pada pemeriksaan perkara anak dalam persidangan. Kata "Wajib di upayakan" mengandung makna bahwa penegak hukum anak dari pentidik, penuntut umum juga hakim diwajibkan untuk melakukan upaya agar proses diversi bisa dilakukan.
\end{abstract}

Kata Kunci : Sistem Peradilan Anak, Diversi, Keadilan Restoratif. 


\section{PENDAHULUAN}

Perlindungan anak merupakan pekerjaan yang penting yang harus terus dilakukan oleh seluruh unsur negara. Anak sebagai bagian dari generasi muda merupakan aset dan penerus cita-cita bangsa memiliki peran strategis dan mempunyai ciri serta sifat khusus yang menjamin kelangsungan eksistensi bangsa dan negara pada masa depan. Anak merupakan harapan orang tua, harapan bangsa dan negara. Oleh karena itu, diperlukan pembinaan secara terus menerus demi kelangsungan hidup, pertumbuhan dan perkembangan fisik, mental dan sosial serta perlindungan dari segala kemungkinan yang membahayakan atau merusak masa depan anak.

Kenakalan anak setiap tahun selalu meningkat apabila dicermati perkembangan tindak pidana yang dilakukan anak selama ini baik dari kualitas maupun modus operandi yang dilakukan, kadang tindakan pelanggaran yang dilakukan anak dirasakan telah meresahkan semua pihak khususnya para orang tua. Selain itu berbagai upaya pencegahan dan penanggulangan kenalan anak perlu segera dilakukan.

Meningkatnya perilaku tindak pidana yang dilakukan oleh anak, semestinya tidak harus terjadi sehingga upaya pencegahan haruslah dilakukan. Salah satu upaya pencegahan dan penanggulangan kenalan anak (politik kriminal anak) saat ini melalui penyelenggaraan sistem peradilan anak (juvenile justice). Tujuan penyelenggaraan sistem peradilan anak tidak sematamata bertujuan untuk menjatuhkan sanksi pidana bagi anak yang telah melakukan tindak pidana, tetapi lebih difokuskan pada dasar pemikiran bahwa penjatuhan sanksi tersebut sebagai sarana mendukung mewujudkan kesejahteraan anak pelaku tindak pidana. Anak yang melakukan pelanggaran hukum atau melakukan tindakan kriminal sangat dipengaruhi beberapa faktor lain diluar diri anak seperti pergaulan, pendidikan, teman bermain, dan sebagainya, karena tindak pidana yang dilakukan oleh anak pada umumnya adalah merupakan proses meniru ataupun terpengaruh tindakan negatif dari orang dewasa atau orang disekitarnya. 
Ketika anak tersebut diduga melakukan tindak pidana, sistem peradilan anak yang pada akhirnya menempatkan anak dalam status narapidana tentunya membawa konsekuensi yang cukup besar dalam hal tumbuh kembang anak. Proses penghukuman yang diberikan kepada anak ke dalam penjara ternyata tidak berhasil menjadikan anak jera dan menjadi pribadi yang lebih baik untuk menunjang proses tumbuh kembangnya. Penjara justru seringkali membuat anak semakin profesional dalam melakukan tindak kejahatan. Untuk melakukan perlindungan terhadap anak dari pengaruh proses formal sistem peradilan pidana, maka timbul pemikiran manusia atau para ahli hukum dan kemanusiaan untuk membuat aturan formal tindak pengeluaran (remove) seorang anak yang melakukan pelanggaran hukum. Oleh karenanya, Negara harus memberikan perlindungan terhadap anak apabila anak tersebut menjadi pelaku tindak pidana. Perlindungan anak ini dapat dilakukan dari segala aspek mulai dari pada pembinaan pada keluarga, kontrol sosial terhadap pergaulan anak dan penanganan yang tepat melalui peraturan-peraturan yang dibuat oleh suatu negara.

Anak bukanlah miniatur orang dewasa, anak mempunyai ciri dan karakteristik tersendiri, sehingga harus diperlakukan secara berbeda (istimewa), memperhatikan hakhaknya, kelangsungan hidupnya kelak dimasa depan, dan juga harus mempertimbangkan kepentingan terbaik bagi anak. Oleh karena itu, dalam Pasal 59 Undang-Undang No 35 Tahun 2014 perubahan atas Undang-Undang No 23 Tahun 2002 Tentang perlindungan anak telah mengatur perlindungan khusus yang dapat diberikan terhadap anak yang berhadapan dengan hukum.

Pemberian perlindungan terhadap anak tidak hanya diberikan kepada anak yang menjadi korban tindak pidana, namun juga kepada anak yang menjadi pelaku tindak pidana, sehingga dalam proses hukum dalam memberikan putusan pidana seharusnya juga mempertimbangkan masa depan anak. Apabila anak berkelakuan baik maka baik pula masa 
depan bangsa itu. Pada sisi yang lain anak merupakan kualitas sumber data manusia sebagai subjek pembangunan bangsa sekarang dan yang akan datang.

Sebagai upaya mengatasi kelemahan Undang-Undang No 3 Tahun 1997 Tentang Pengadilan Anak, maka diberlakukan Perubahan fundamental dalam Undang-Undang No 11 Tahun 2012 Tentang Sistem Peradilan Pidana Anak dengan digunakan pendekatan restoratif justice melalui sistem diversi. Dalam peraturan ini diatur mengenai kewajiban para penegak hukum dalam mengupayakan diversi (penyelesaian melalui jalur non formal) pada seluruh tahapan proses hukum. Ketentuan yang terdapat dalam Undang-Undang No 11 Tahun 2012 Tentang Sistem Peradilan Pidana Anak yang hanya memungkinkan diversi diberlakukan oleh penyidik berdasarkan kewenangan diskresioner yang dimilikinya dengan cara menyerahkan anak yang berhadapan dengan hukum kepada orang tua, wali atau orang tua asuhnya.

Proses peradilan perkara anak sejak ditangkap, ditahan dan di adili pembinaannya wajib dilakukan oleh pejabat khusus yang memahami masalah anak. Namun sebelum masuk proses peradilan, para penegak hukum, keluarga dan masyarakat wajib mengupayakan proses penyelesaian diluar jalur pengadilan yakni melalui diversi berdasarkan pendekatan keadilan restoratif. Berdasarkan Pasal 8 Ayat (1) Undang-Undang No 11 Tahun 2012 Tentang Sistem Peradilan Pidana Anak, Proses diversi adalah : "Proses Diversi dilakukan melalui musyawarah dengan melibatkan anak dan orang tua/walinya, korban dan/atau orang tua/walinya, pembimbing kemasyarakatan dan pekerja sosial profesional berdasarkan pendekatan keadilan restoratif'. Akan tetapi, proses diversi ini hanya dapat dilakukan untuk tindak pidana yang dilakukan dengan pidana penjara di bawah 7 (tujuh) tahun dan bukan merupakan pengulangan tindak pidana.

Berdasarkan uraian tersebut maka peneliti tertarik untuk melakukan penelitian yang tentang Penerapan Diversi Undang-Undang No 11 Tahun 2012 Tentang Sistem Peradilan Anak. Adapun permasalah yang diteliti penulis yakni : (1) Bagaiamana penerapan Diversi 
Undang-Undang No 11 Tahun 2012 Tentang Sistem Peradilan Pidana Anak.; (2) Bagaimana pengawasan terhadap pelaksanaan Diversi Undang-Undang No 11 Tahun 2012 Tentang Sistem Peradilan Pidana Anak.

Tidak menutup kemungkinan banyak yang menggunakan anak sebagai sarana peredaran narkotika karena banyak pihak menganggap anak memiliki sedikit kekebalan hukum bila mengacu pada Undang-Undang Sistem Peradilan Anak. Banyak kasus anak yang melakukan tindak kejahatan tidak diproses secara hukum melainkan dikembalikan kepada orang tua, terutama anak dibawah 12 tahun (Primawardani \& Kurniawan 2017). Dalam menyelesaikan perkara anak, anak harus diberlakukan secara khusus. Perlindungan khusus ini terdapat pada Pasal 17 ayat (1) Undang-Undang Sistem Peradilan Pidana Anak. Hal ini mengingat sifat dan psikis anak dalam beberapa hal tertentu memerlukan perlakuan khusus, serta perlindungan yang khusus pula, terutama pada tindakan-tindakan yang dapat merugikan perkembangan mental maupun jasmani anak (Danielt 2014).

Kesejahteraan anak akan mudah tercipta saat anak sudah diperlakukan dengan baik. Maksud dari diperlakukan dengan baik disini adalah terpenuhinya semua kebutuhan dan hak dasar.Bukan hanya itu, anak juga dapat mengembangkan dirinya di lingkungan sosialnya (Fitri, Riana \& Fedryansyah 2015). Berbicara mengenai hak, pasti di sisi lain ada kewajiban. Relasi orang tua dan anak, mengenai hak dan kewajiban mereka dalam Islam, adalah seperti yang digambarkan hadis Nabi Muhammad Saw : "Tidak termasuk golongan umatku, mereka yang (tua) tidak menyayangi yang muda, dan mereka yang (muda) tidak menghormati yang tua" (Siswadi 2011).

Perdagangan orang (trafficking in persons) merupakan kejahatan yang keji terhadap Hak Asasi Manusia (HAM), yang mengabaikan hak seseorang untuk hidup bebas, tidak disiksa, kebebasan pribadi, pikiran dan hati nurani, beragama, hak untuk tidak diperbudak dan lainnya (Utami \& Putranto 2002). Tujuan dilakukannya pemidanaan terhadap seseorang yang 
terbukti melakukan tindak pidana sesuai dengan bunyi pada Pasal 54 KUHP adalah mencegah dilakukannya tindak pidana dengan menegakkan norma hukum, memasyarakatkan terpidana dengan mengadakan pembinaan, menyelesaikan konflik yang ditimbulkan oleh tindak pidana, dan membebaskan rasa bersalah pada terpidana (Murniyati 2013).

\section{METODE PENELITIAN}

Dalam melakukan penelitian ini peneliti menggunakan pendekatan Yuridis Empiris dimana penelitian ini dilakukan terhadap keadaan yang nyata bagi masyarakat atau lingkungan disekitar dengan maksud dan tujuan untuk mememukan fakta dan kemudian menuju kepada penyelesaian masalah. Penelitian ini akan dilaksanakan di Polres Sorong Kota tepatnya pada unit Pelayanan Perempuan dan Anak (PPA).

Teknik pengumpulan data yang digunakan peneliti selama melaksanakan penelitian di Polres Sorong Kota yakni Melakukan wawancara secara langsung dalam bentuk tanya jawab dengan responden.

Adapun analisis data yang peneliti gunakan adalah Analisis Normatif yakni kajian secara deskriftif kualitatif terhadap data sekunder yakni Pasal-Pasal yang termuat dalam KUHP dan Undang-Undang Sistem Peradilan Pidana Anak. Hasil yang diperoleh melalui studi kepustakaan dan juga wawancara secara langsung tersebut disusun secara sistematif dan analisis sesuai dengan metode pendekatan normatif empiris maka pendekatan yang digunakan adalah Analisis secara deskrifitif kualitatif yakni data yang bertitik tolak pada upaya dalam menemukan asas-asas dan teori dalam menganalisis masalah dalam penelitian ini. Hal ini dimaksudkan agar peneliti dapat menggambarkan keseluruhan hasil data yang diperoleh baik melalui wawancara maupun melalui studi pustaka. Selain itu peneliti berhadap dapat menggambarkan pendapat para ahli atau pakar hukum, maupun referensi-referensi yang telah dikumpulkan. Dari semua hasil yang diperoleh peneliti diharapkan dapat dianalisis yang 
nantinya akan dihubungkan dengan rumusan peraturan perUndang-Undang yang ada dan dapat diambil kesimpulan atau jawaban guna menjawab permasalahan yang diteliti oleh penulis.

\section{PEMBAHASAN}

\section{Penerapan Diversi Undang-Undang No 11 Tahun 2012 Tentang Sistem Peradilan Pidana}

Anak

Undang-Undang No 3 Tahun 1997 Tentang Pengadilan Anak yang diharapkan menjadi jawaban atas masalah anak, masih belum dapat memenuhi kepentingan terbaik anak, karena paradigma dalam Undang-Undang ini masih berorientasi pada dimensi pidana pembalasan (retributif justice). Sementara penggunaan sanksi pidana yang lebih dominan dalam penanganan anak yang berkonflik dengan hukum tidak mampu menghindarkan anak dari stigma negatif dari proses peradilan pidana dan tidak mampu memulihkan anak dari perilaku kenakalannya yang berdampak adanya pengulangan kenakalan (re-offending).

Selain itu pemenjaraan sebagai upaya utama (premium remidiumn) dalam menangani anak yang berhadapan dengan hukum sangat bertentangan dengan prinsip yang terdapat dalam Resolusi Perserikatan Bangsa-Bangsa Nomor 45/113 Tentang Peraturan PBB bagi perlindungan anak yang kehilangan kebebasannya yang menyatakan bahwa:

1. Imprisonment should be used a last resort Pidana penjara harus digunakan sebagai upaya terakhir.

2. Deprivation of the liberty of a juvenile should be a disposition of last resort and the minimum necessary period and should be limited to exceptional cases (perampasan kemerdekaan anak harus di tetapkan sebagai upaya terakhir dan untuk jangka waktu minimal yang diperlukan, serta dibatasi untuk kasus-kasus yang luar biasa.

Disamping itu lembaga pemasyarakatan di seluruh indonesia yang banyak mengalami over capacity tidak memperhatikan kepentingan terbaik baik anak sehingga pelayanan hak 
anak selama ini didalam penjara tidak terpenuhi dengan baik. Keadaan ini tidak bersesuaian dengan prinsip yang terdapat dalam Pasal 3 Kovensi Hak Anak yang menyatakan :

1. Dalam semua tindakan mengenai anak yang dilakukan oleh lembaga kesejahteraan sosial negara atau swasta, pengadilan hukum, penguasa administratif atau badan legislatif, kepentingan terbaik anak harus merupakan pertimbangan utama.

2. Negara berusaha menjamin perlindungan dan perawatan anak seperti yang diperlukan untuk kesejahteraan dengan memperhatikan hak-hak dan kewajiban orang tuanya, wali hukumnya atau orang lain yang secara sah atas dia, dan untuk tujuan ini, harus mengambil semua tindakan legislatif dan administratif yang tepat.

3. Negara harus menjamin bahwa berbagai lembaga, pelayan dan fasilitas yang bertanggung jawab atas perawatan dan perlindungan tentang anak, harus menyesuaikan diri dengan standar yang ditentukan oleh para penguasa yang berwenang, terutama dibidang keselamatan, kesehatan dalam jumlah dan kesesuaian staf.

Terkait hal tersebut, dalam Undang-Undang No 11 Tahun 2012 Tentang Sistem Peradilan Anak huruf d menyatakan bahwa Undang-Undang No 3 Tahun 1997 Tentang Pengadilan Anak sudah tidak sesuai lagi dengan perkembangann dan kebuthan hukum masyarakat karena belum secara konfrehensif memberikan perlindungan kepada anak yang berhadapan dengan hukum sehingga perlu diganti dengan Undang-Undang yang baru yaitu Undang-Undang No 11 Tahun 2012 Tentang Sistem Peradilan Pidana Anak.

Undang-Undang No 11 Tahun 2012 Tentang Sistem Peradilan Pidana Anak mengubah paradigma penegakan hukum terhadap anak. Aspek yang lebih ditekankan dalam UndangUndang ini adalah pengalihan penyelesaian perkara anak dari proses peradilan anak ke proses diluar pengadilan pidana (Diversi) dan wajib mengutamakan pendekatan keadilan restoratif. Keadilan restoratif adalah penyelesaian perkara tindak pidana dengan melibatkan pelaku, korban, keluarga pelaku/korban, dan pihak lain yang terkait untuk bersama-sama mencari 
penyelesaian yang adil dengan menekankan pemulihan kembali pada keadaan semula dan bukan pembalasan. Keadilan restoratif ini diupayakan melalui diversi sejak tingkat penyidikan, penuntutan dan pengadilan.

Undang-Undang No 35 Tahun 2014 Tentang Perlindungan Anak tidak secara khusus dan eksplisit mengatur tentang pelaksanaan metode Diversi dalam menyelesaikan masalah tindak pidana yang dilakukan oleh anak. Namun, bila diperhatikan sebenarnya UndangUndang ini mengusung niat untuk menyelesaikan masalah anak dengan cara menjamin perlindungan anak. Pasal 3 Undang-Undang ini menyebutkan mengenai tujuan dari perlindungan anak yaitu untuk memberikan jaminan sepenuhnya hak-hak agar terhindar dari kekerasaan, diskriminasi dengan harapan terwujudnya masa depan anak Indonesia yang berkualitas, berakhlak mulia dan sejahtera.

Dalam melaksanakan diversi harus dipertimbangan tentang kategori tindak pidana, umur anak, hasil penelitian kemasyarakatan dari Bapas dan dukungan lingkungan keluarga dan masyarakat. Syarat kesepakatan diversi ada 2 (dua) yakni :

1. Harus mendapat persetujuan korban dan/atau keluarga anak korban serta kesediaan anak dan keluarganya. Hasil kesepakatan diversi dalam konteks ini dapat berbentuk antara lain perdamaian dengan atau tampa rugi, penyerahan kembali kepada orang tua/wali, keikutsertaan dalam pendidikan atau Lembaga Penempatan Anak Sementara (LPKS) paling lama 3 (tiga) bulan atau pelayanan Masyarakat.

2. Tidak harus mendapat persetujuan korban dan/atau keluarga anak korban serta kesediaan anak dan keluarganya untuk tindak pidana yang berupa pelanggaran, tindak pidana tingan, tindak pidana tanpa korban, atau nilai kerugian korban tidak melebihi dari nilai upah minimum provinsi setempat. Terhadap aspek ini kesepakatan diversi dapat dilakukan oleh penyidik bersama pelaku dan/atau keluarganya, pembimbing kemasyarakatan, serta dapat melibatkan tokoh masyarakat. Kemudian kesepakatan diversi bentuknya dapat berupa 
pengembalian kerugian dalam hal ada korban, rehabilitasi medis dan psikososial, penyerahan kembali kepada orang tua/wali, keikutsertaan dalam pendidikan atau pelatihan di lembaga pendidikan atau Lembaga Penempatan Anak Sementara (LPKS) paling lama 3 (tiga) bulan.

\section{Pengawasan Pelaksanaan Terhadap Diversi di Polres Sorong Kota}

Diversi sebagai upaya terakhir dalam penyelesaian perkara anak diluar peradilan pidana anak sesuai dengan amanat dalam Undang-Undang No 11 Tahun 2012 Tentang Sistem Peradilan Pidana Anak dilakukan dengan memperhatikan kepentingan terbaik bagi anak. Namun tidak semua perkara yang melibatkan anak dapat dilaksanakan upaya diversi, karena ada syarat-syarat yang diatur dalam Undang-Undang ini mengenai pelaksanaan diversi seperti yang termuat dalam Pasal 7 dan 9 Undang-Undang ini yakni yang dapat dilakukan upaya diversi apabila tindak pidana yang dilakukan diancam dengan pidana penjara di bawah 7 (tujuh) tahun dan bukan merupakan pengulangan tidak pidana, mendapatkan persetujuan korban dan/atau keluarga korban kecuali untuk tindak pidana yang berupa pelanggaran, tindak pidana ringan, tindak pidana tanpa korban, tindak pidana tidak lebih dari upah minimum provinsi setempat dan adanya kesediaan anak dan keluarganya.

Proses diversi dilakukan melalui musyawarah dengan melibatkan anak dan orang tua/walinya, korban dan/atau orang tua/walinya, Pembimbing Kemasyarakatan, Pekerja Sosial Profesional berdasarkan pendekatan keadilan restoratif. Dalam hal diperlukan musyawarah dapat melibatkan tenaga kesejahteraan sosial dan/atau masyarakat. Proses diversi wajib memperhatikan kepentingan korban, kesejahteraan dan tanggung jawab anak, penghindaraan stigma negatif, menghindarkan pembalasan, kesusilaan dan ketertiban umum.

Pengawasan atas proses diversi dan pelaksanaan kesepakatan yang dihasilkan berada pada atasan langsung pejabat yang bertanggung jawab disetiap tingkat pemeriksaan. Selama proses diversi berlangsung sampai pada kesepakatan diversi dilaksanakan, pembimbing 
kemasyarakatan wajib melakukan pendampingan, pembimbingan dan pengawasan. Dalm hal kesepakatan diversi tidak dilaksanakan dalam waktu yang ditentukan, pembimbing kemasyarakatan segera melaporkan kepada pejabatan yang bertanggung jawab sesuai tingkat pemeriksaan dan pejabat yang bertanggung jawab tersebut wajib menindaklanjuti laporan pembimbing kemasyarakatan dalam waktu paling lama 7 (tujuh).

\section{SIMPULAN}

Diversi wajib diupayakan pada tingkat penyidikan, tingkat penuntutan maupun pada pemeriksaan perkara anak dalam persidangan. Kata "Wajib diupayakan" mengandung makna bahwa penegak hukum anak mulai dari penyidik, penuntut umum juga hakim diwajibkan untuk melakukan upaya agar proses diversi bisa dilaksanakan. Polres Sorong Kota lebih khusus Unit Pelayanan Pidana Anak sebagai penyidik anak sejak berlakunya Undang-Undang No 11 Tahun 2012 telah menerapkan diversi sebagai proses penyelesaian perkara anak dengan mengutamakan pendekatan restorative justice yang melibatkan pelaku, korban, keluarga pelaku/korban dan pihak yang terkait untuk bersama-sama mencari penyelesaian yang adil guna kepentingan terbaik bagi anak.

\section{DAFTAR PUSTAKA}

\section{Buku}

Ahmad Sofian, 2012, Perlindungan Anak di Indonesia Dilema dan Solusinya,PT.Sofmedia, Jakarta.

Marlina, Peradilan Pidana Anak Di Indonesia, Pengembangan Konsep Diversi Dan Restorative Justice, Refika Aditama, Bandung, 2009

Rufinus H. Hutauruk, Penanggulangan Kejahatan Koorporasi Melalui Pendekatan Restoratif ,Sinar Grafika, Jakarta 2013

Soerjono Soekanto, 1986, Pengantar Penelitian Hukum, VI.Press, Jakarta.

\section{Jurnal}

Andri Yoga Utami dan Pandji Putranto. (2002). Ketika Anak Tak Bisa Lagi Memilih : Fenomena Anak yang Dilacurkan di Indonesia, Kantor Perburuhan, Jakarta. 
Anissa Nur Fitri, Agus Wahyudi Riana, \& Muhammad Fedryansyah. (2015). Perlindungan Hak-Hak Anak Dalam Upaya Peningkatan Kesejahteraan Anak. Prosiding Ks: Riset \& Pkm, 2 (1), 45-50

Imran Siswadi. (2011). Perlindungan Anak Dalam Perspektif Hukum Islam Dan Ham. AlMawarid Journal of Islamic Law. 9 (2). 225-239.

Ni Nyoman Murniyati. (2015). Sistem Pemidanaan Terhadap Pelaku Tindak Pidana Perdagangan Anak Di Indonesia. Journal Ilmu Hukum. 1 (4). 1-5.

Reyner Timothy Daniel. (2014). Penerapan Restorative Justice Terhadap Tindak Pidana Anak Pencurian Oleh Anak Di Bawah Umur. Lex et Societatis. 2 (6). 16-26.

Yuliana Primawardani \& Arief Rianto Kurniawan. (2017). Pendekatan Humanis Dalam Penanganan Anak Pelaku Tindak Pidana Penyalahgunaan Narkoba. Jurnal Penelitian Hukum De Jure. 17 (4). 411-427.

\section{Perundang-Undangan}

Undang-Undang No 11 Tahun 2012 Tentang Sistem Peradilan Pidana Anak.

Undang-Undang No 35 Tahun 2014 Tentang Perlindungan Anak. 